\title{
Records of the Ornate Hawk-eagle, Spizaetus ornatus (Daudin, 1800) (Accipitridae), from the state of São Paulo, southeastern Brazil
}

\author{
Vagner Cavarzere ${ }^{1}$, Gustavo Muniz ${ }^{2}$, Paulo Antonio Silva ${ }^{3}$, Wilton Felipe Teixeira ${ }^{3}$
}

1 Universidade Tecnológica Federal do Paraná, Prolongamento da Rua Cerejeira, s/n, CEP 85892-000, Santa Helena, PR, Brazil. 2 Programa de Voluntariado da Fundação Florestal. Rua Pedro Ferreira Carapeba, 105, CEP: 13607-084, Araras, SP, Brazil. 3 Universidade do Oeste Paulista, Rodovia Raposo Tavares, km 572, CEP 19026-310, Presidente Prudente, SP, Brazil.

Corresponding author: Vagner Cavarzere, vagnera@utfpr.edu.br.

\begin{abstract}
We review the distribution of the Ornate Hawk-eagle, Spizaetus ornatus (Daudin, 1800), in the state of São Paulo, reporting localities with records of the species. Most locations where the species has been historically documented have no recent records, especially to the west of the large remnants of forest in the coastal mountain ranges. Most current records come from Serra de Paranapiacaba, southwestern São Paulo, whereas no records exist within the Cerrado domain. Unlike the neighboring state of Minas Gerais, where it is found in fragmented landscapes, in São Paulo, the species occurs exclusively within protected areas in large blocks of Atlantic Forest.
\end{abstract}

Key words

Atlantic Forest; threatened species; semideciduous forests; Cerrado phytogeographic domain.

Academic editor: Rafael Antunes Dias | Received 28 May 2018 | Accepted 5 July 2018 | Published 10 August 2018

Citation: Cavarzere V, Muniz G, Silva PA, Teixeira WF (2018) Records of the Ornate Hawk-eagle Spizaetus ornatus (Daudin, 1800) (Accipitridae) from the state of São Paulo, southeastern Brazil. Check List 14 (4): 651-655. https://doi.org/10.15560/14.4.651

\section{Introduction}

The Ornate Hawk-eagle, Spizaetus ornatus (Daudin $1800)$, is a medium-sized (56-65 cm, wingspan 107-127 $\mathrm{cm})$, distinctive eagle of the family Accipitridae. The species is widely distributed in tropical forests throughout Central and South America, occurring from sea level up to $1,800 \mathrm{~m}$ a.s.1. in southeastern Mexico south to Brazil, Paraguay and northern Argentina (Ferguson-Lees and Christie 2001). Usually seen lonely or in pairs, it inhabits primarily the interior of large forested areas, where it frequently soars above the canopy. It is often seen foraging at forest edges, foothills, along rivers and other openings (Ferguson-Lees and Christie 2001, Whitacre et al. 2012).

Although still regularly found in the Amazon, southern populations of the species have declined due to extensive deforestation and persecution (Thiollay 1994, Bildstein et al. 1998, Zilio 2017). The species is listed as regionally endangered in all southern and southeastern Brazilian states (Bergallo 2000, Straube et al. 2004, Simon et al. 2007, Silveira et al. 2009, COPAM 2011, São Paulo 2014), except in Santa Catarina and Rio Grande do Sul, where it is considered critically endangered (CONSEMA 2011, Rio Grande do Sul 2014). Spizaetus ornatus was recently rediscovered in the southernmost Brazilian state of Rio Grande do Sul, where it was considered regionally extinct (e.g. Mendonça-Lima et al. 2006), while questionable historical records from northeastern Brazil (Carlos and Girão 2006) are now corroborated by a recording from the Caatinga domain (Cerqueira et al. 2015). 

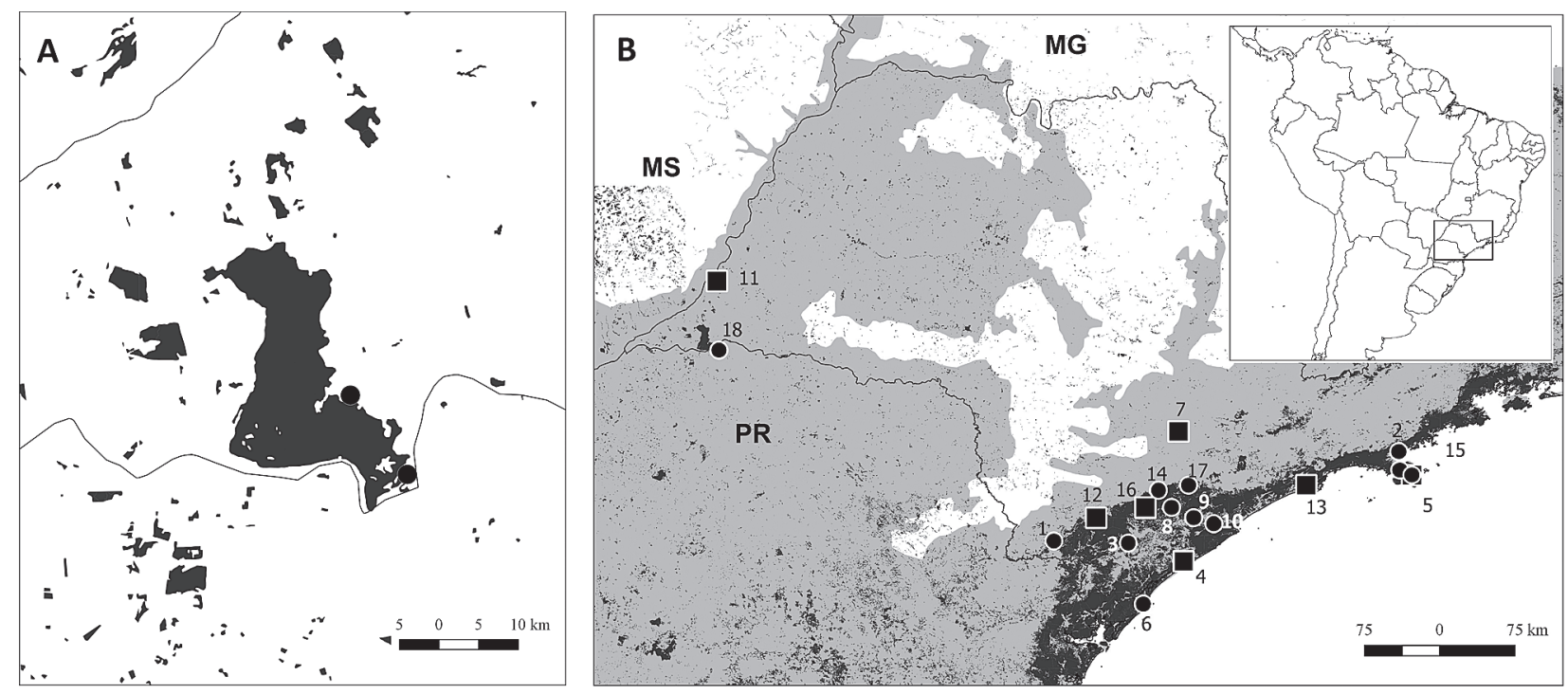

Figure 1. Locations with records of Spizaetus ornatus in the state of São Paulo, southeastern Brazil. A. Localities of recent records within Morro do Diabo State Park. B. All records of the species in São Paulo. Squares represent historical records (pre-1980s) and circles show recent records. Numbers are cross-referenced with Table 1. Light grey indicates the Atlantic Forest phytogeographic domain, while dark gray indicates remnants of the original vegetation; white represents the Cerrado domain.

Here we report the first 2 documented records of Spizaetus ornatus from the interior semideciduous forests from São Paulo and present an update of its distribution within this state.

\section{Methods}

We searched for records of $S$. ornatus in the literature and in the on-line databases E-Bird, the Internet Bird Collection, Macaulay Library, Wiki Aves and Xeno-canto up to 27 May 2018. In addition, we report the first documented records from the 34,000 ha Morro do Diabo State Park (Fig. 1), in Teodoro Sampaio municipality, westernmost São Paulo state.

\section{Results}

We compiled 22 records of $S$. ornatus from 18 locations within the state of São Paulo (Table 1). Of these, 11 are historical records spanning from the 19th century up to the 1980s, while the remaining half are from the 2000s up to the present. The sole interior record for semideciduous forests are museum specimens from Barra do Ribeirão dos Guachos, municipality of Presidente Epitácio (Willis and Oniki 2003), on the left bank of the Paraná river, western São Paulo. There are 5 specimens collected at the Ipanema National Forest in the $19^{\text {th }}$ century (Pelzeln 1868). Records in the state show that for the last 39 years, the species seems restricted to protected areas within the 2 mountain ranges along the coast, the Serra do Mar and especially the Serra de Paranapiacaba (Granzinolli 2009).

In addition to the records presented by Granzinolli (2009), there are a few other records of $S$. ornatus within São Paulo in the on-line databases Internet Bird Collection and Wiki Aves (Table 1, Fig. 1). With one exception, all recent records are restricted to protected areas.
New records. Brazil: São Paulo, Teodoro Sampaio, Morro do Diabo State Park, headquarters (22 $37^{\prime} 15.59^{\prime \prime}$ S, 052 $\left.10^{\prime} 09.89^{\prime \prime} \mathrm{W}, 270 \mathrm{~m}\right)$, Vagner Cavarzere, 19 January 2015 (photographed adult individual opportunistically hand-captured by park rangers); Brazil: São Paulo, Teodoro Sampaio, Morro do Diabo State Park, Linhão Trail (22ْ32'26.73" S, 052 $12^{\circ} 48.34^{\prime \prime} \mathrm{W}, 270$ m), Gustavo Muniz, 11 November 2017 (adult individual photographed, Fig. 2). Park rangers reported S. ornatus was following a mid-sized bird (the description of which was not accurate enough to be identified) at $18.30 \mathrm{~h}$ close to the forest edge. As the raptor failed on its attempt, it hit the ground and was unable to fly due to the tall Urochloa sp. grass on which it fell. A park ranger photographed the individual, which was then released. We examined the photograph and confirmed its identity and age. On the second occasion, during systematic bird surveys, Gustavo Muniz played back its vocalization, to which it promptly responded at $18.24 \mathrm{~h}$.

Identification. We readily identified these individuals as Spizaetus ornatus due to the characteristic black crown and crest, with chestnut on the sides of the head and yellow legs (Ferguson-Lees and Christie 2001).

\section{Discussion}

Unlike records obtained in the state of Minas Gerais, where the species has been commonly recorded in semiopen areas and severely fragmented landscapes (Zorzin et al. 2006, Salvador-Jr 2011, Canuto et al. 2012), all available records from São Paulo suggest that $S$. ornatus is found in areas with large blocks of forest; there are no records from highly fragmented landscapes. Historical accounts are from formerly continuous forested areas. In addition, in São Paulo, the species does not occur within the Cerrado phytogeographic domain. 


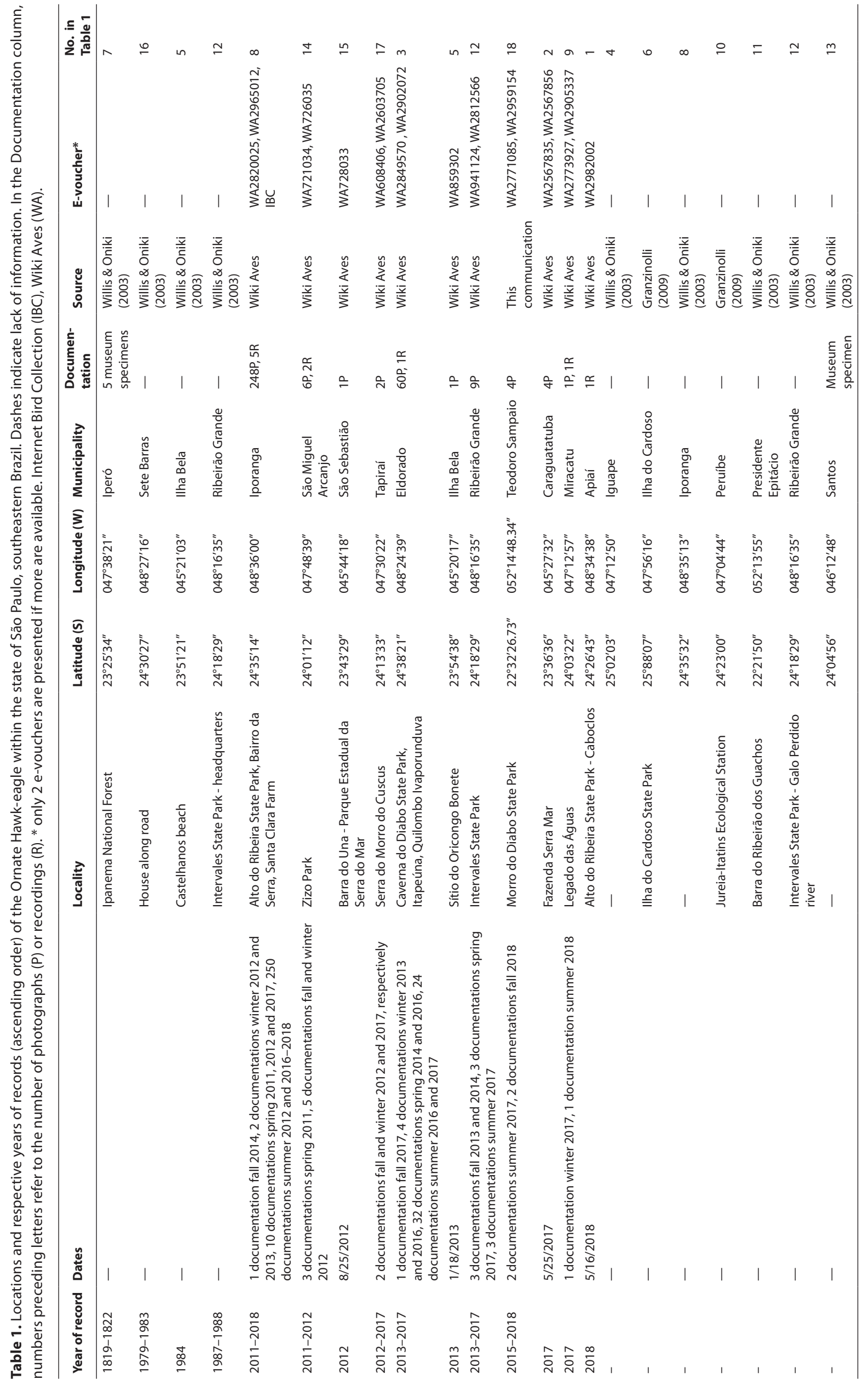




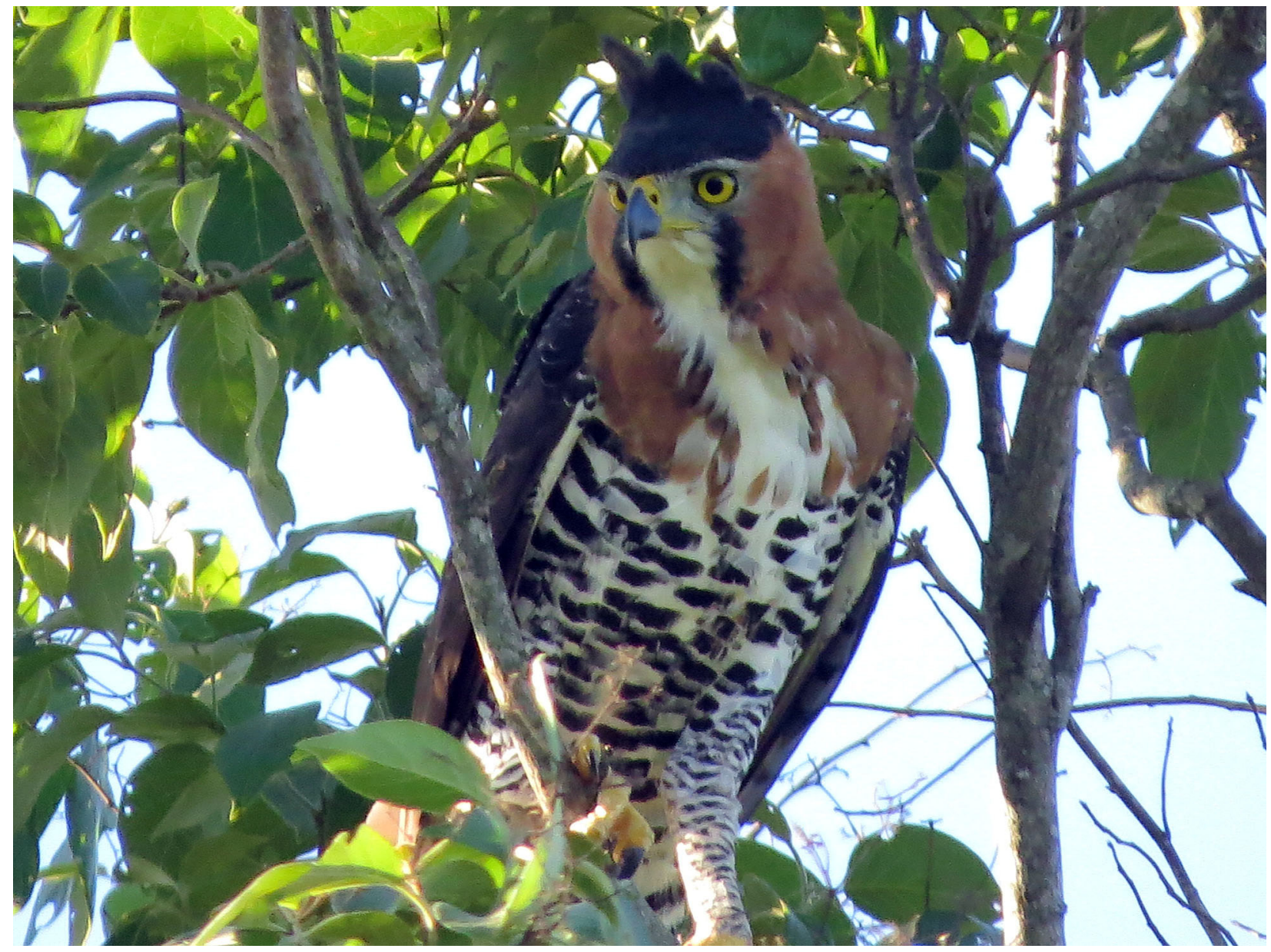

Figure 2. Adult individual of Spizaetus ornatus photographed after play back at Morro do Diabo State Park, westernmost state of São Paulo, southeastern Brazil. (Photographed by Gustavo Muniz).

Uezu (2006) failed to record the species at Morro do Diabo State Park between 2002 and 2005. Because of an unpublished and undocumented previous sighting of the species, at that time he suggested it was highly threatened and probably extinct in the reserve. Likewise, no records come from the Mantiqueira mountain range. However, as there is suitable habitat for the species, we predict it is likely to be recorded within the Mantiqueira mountain range in São Paulo as well as in the states of Minas Gerais and Rio de Janeiro. Similar to what occurred in Morro do Diabo State Park, it may have been overlooked due to its low densities and large home ranges, estimated to be approximately $19 \mathrm{~km}^{2}$ for adult males (Whitacre et al. 2012).

Pristine or mature secondary forests at the 5,000 ha Ipanema National Forest are long gone and the species has not been recorded there since the 19th century (Cavarzere et al. 2017). In Presidente Epitácio, where the species has also been previously recorded, there are still some relatively large (ca 500 ha) remnants. We suggest $S$. ornatus may be detected there if these forest remnants are exhaustively surveyed, but we reinforce the species requires large, unbroken forest areas, confirming its critical situation in the Atlantic Forest (Zilio 2017).

\section{Acknowledgements}

We thank Eriqui Marqueti Inazaki, Morro do Diabo State Park's manager, for his commitment to research conducted at the park. Fundação Florestal, Instituto Florestal and Comissão Técnico Científica made this project possible. Authors complied with regulatory documents of normative ordinance FF/DE ${ }^{\circ} 236$ de 01/03/2016. VC thanks Guilherme S. T. Garbino, Museu de Zoologia da Universidade de São Paulo (MZUSP), IdeaWild, The Rufford Foudation, CNPq (503496/2014-6), Djalma Weffort (Apoena) and Milton C. Ribeiro. Fabio Schunck, Felipe Zilio and Rafael A. Dias contributed significantly to improve a previous version of this manuscript.

\section{Authors' Contributions}

VC obtained photographs of one specimen caught by park rangers during another project and wrote the text; GM photographed one specimen; PAS and WFT wrote the text.

\section{References}

Bergallo HG (2000) A Fauna Ameaçada de Extinção do Estado do Rio de Janeiro. EdUERJ, Rio de Janeiro, Brazil, 166 pp. 
Bildstein KL, Schelsky W, Zalles J (1998) Conservation status of tropical raptors. Journal of Raptor Research 32 (1): 3-18.

Canuto M, Zorzin G, Carvalho Filho EPM, Carvalho CEA, Carvalho GDM, Benfica CERT (2012) Conservation, Management and Expansion of Protected and Non-Protected Tropical Forest Remnants Through Population Density Estimation, Ecology and Natural History of Top Predators; Case Studies of Birds of Prey (Spizaetus taxon). In: Sudarshana P, Nageswara-Rao M, Soneji JR (Eds) Tropical Forests, InTech, Rijeka, Croatia, 359-388. https:// doi.org/10.5772/30059

Cavarzere V, Silveira L, Tonetti VR, Develey P, Ubaid FK, Regalado LB, Figueiredo LFA (2017) Museum collections indicate bird defaunation in a biodiversity hotspot. Biota Neotropica 17 (4): e20170404. http://doi.org/10.1590/1676-0611-bn-2017-0404

Cerqueira PV, Gonçalves GSR, Sousa SA, Paz RL, Landim AS, Santos MPD (2015) First record of the Ornate Hawk-eagle (Spizaetus ornatus) from the Brazilian Caatinga. The Wilson Journal of Ornithology 127 (1): 153-156. http://doi.org/10.1676/14-076.1

Carlos CJ, Girão W (2006) A história do gavião-de-penacho, Spizaetus ornatus, na floresta Atlântica do nordeste do Brasil. Revista Brasileira de Ornitologia 14 (4): 405-409.

CONSEMA - Conselho Estadual de Meio Ambiente (2011) Lista Oficial de Espécies da Fauna Ameaçadas de Extinção no Estado de Santa Catarina. Resolução CONSEMA n 2, de 06 de Dezembro de 2011. Secretaria de Estado do Desenvolvimento Econômico e Sustentável, Florianópolis, 19 pp.

Ferguson-Lees J, Christie DA (2001) Raptors of the World. Mifflin Company, New York, 992 pp.

Granzinolli MAM (2009) Spizaetus ornatus (Daudin, 1800). Falconiformes, Accipitridae. In: Bressan M, Kierulff MCM, Sugieda AM (Eds) Fauna Ameaçada de Extinção no Estado de São Paulo: Vertebrados. São Paulo, Fundação Parque Zoológico de São Paulo, Secretaria do Meio Ambiente, São Paulo, Brazil, 143 pp.

Mendonça-Lima A, Zilio F, Joenck CM, Barcellos A (2006) Novos registros de Spizaetus ornatus (Accipitridae) no sul do Brasil. Revista Brasileira de Ornitologia 14 (3): 279-282.

Pelzeln A (1868) Zur Ornithologie Brasiliens. Resultate von Johann Natterers Reisen in den Jahren 1817 bis 1835. A. Pichler's Witwe and Sohn, Viena, Austria, 556 pp.

Rio Grande do Sul (2014) Lista das espécies da fauna ameaçadas de extinção no estado do Rio Grande do Sul. Instrução Normativa ${ }^{\circ}$ 3. DECRETO No 51.797. Diário Oficial do Estado do Rio Grande do Sul, Secretaria do Meio Ambiente, Porto Alegre, 4 pp.
Salvador LF Jr, Canuto M, Carvalho CEA, Zorzin G (2011) Aves, Accipitridae, Spizaetus tyrannus (Wied, 1820): new records in the Quadrilátero Ferrífero region, Minas Gerais, Brazil. Check List 7 (1): 32-36. https://doi.org/10.15560/7.1.32

São Paulo (2014) Decreto ${ }^{\circ}$ 60.133, de 7 de fevereiro de 2014. Declara as espécies de fauna silvestre ameaçadas de extinção, as quase ameaçadas e as deficientes de dados para avaliação no Estado de São Paulo e dá providências correlatas. https:/www.al.sp.gov.br/ repositorio/legislacao/decreto/2014/decreto-60133-07.02.2014. html. Accessed on: 2018-02-18.

Silveira LF, Benedicto GA, Schunck F, Sugieda AM (2009) Aves. In: Bressan PM, Kierulff MCM, Sugieda AM (Eds) Fauna Ameaçada de Extinção no Estado de São Paulo: Vertebrados. Fundação, Parque Zoológico de São Paulo: Secretaria do Meio Ambiente, São Paulo, 87-284.

Simon JE, Antas PTZ, Pacheco JF, Efe M, Ribon R, Raposo MA, Laps R, Musso C, Passamani J, Paccagnela SG (2007) As Aves Ameaçadas de Extinção no Estado do Espírito Santo. In: Mendes SL, Passamani M (Eds) Livro Vermelho das Espécies da Fauna Ameaçada de Extinção no Estado do Espírito Santo. IPEMA, Vitória, Brazil, 47-68.

Straube FC, Urben-Filho A, Kajiwara D (2004). Aves. In: Mikich SB, Bérnils RS [Eds] Livro Vermelho da Fauna Ameaçada no Estado do Paraná. Instituto Ambiental do Paraná, Curitiba, 143-496.

Thiollay JM (1994) Family Accipitridae (Hawks and Eagles). In: del Hoyo J, Elliott A, Sargatal J (Eds) Handbook of the Birds of the World. Vol. 2. New World Vultures to Guineafowl. Lynx Edicions, Barcelona, Spain, 52-215.

Uezu A (2006) Composição e estrutura da comunidade de aves na paisagem fragmentada do Pontal do Paranapanema. PhD dissertation, Universidade de São Paulo, São Paulo, Brazil, 193 pp.

Whitacre DF, Madrid JA, Madrid HD, Cruz R, Flatten CJ, Funes SH (2012) Ornate Hawk-Eagle. In Whitacre DF (Ed) Neotropical Birds of Prey: Biology and Ecology of a Forest Raptor Community. Cornell University Press, Ithaca, 203-233.

Willis EO, Oniki Y (2003) Aves do Estado de São Paulo. Divisa, Rio Claro, Brazil, 398 pp.

Zilio F (2017). Breeding biology and conservation of hawk-eagles (Spizaetus spp.) Aves, Accipitridae) in southern Atlantic Forest, Brazil. Iheringia 107: e2017037. http://doi.org/10.1590/16784766e2017037

Zorzin G, Carvalho CEA, Carvalho Filho EPM, Canuto M (2006) Novos registros de Falconiformes raros e ameaçados para o Estado de Minas Gerais. Revista Brasileira de Ornitologia 14 (4): 417-421. 